\section{Compaction characteristics of lateritic soils stabilised with cement-calcined clay blends}

G. Matthew AYININUOLA - Civil Engineering Department, University of Ibadan, Nigeria O. Aroola ADEKITAN - Civil Engineering Department, Moshood Abiola Polytechnic, Abeokuta Nigeria * adekitan.olasunkanmi@mapoly.edu.ng

Érkezett: 2017. 01. 06. " Received: 06. 01. 2017. - https://doi.org/10.14382/epitoanyag-jsbcm.2017.7
G. Matthew AYININUOLA holds a PhD in Geotechnical Engineering. He is currently an Associate Professor with the Department of Civil Engineering, University of Ibadan, Ibadan, Nigeria.

0. Ayoola ADEKITAN is currently with the Department of Civil Engineering, Moshood Abiola Polytechnic, Abeokuta, Nigeria and a PhD student with the Department of Civil Engineering, University of Ibadan, Ibadan, Nigeria

\begin{abstract}
Investigations on the potentials of pozzolans - silicate and aluminate materials - in civil engineering works is on the rise. Calcined kaolinite clay (CKC) is one of such pozzolans that has been regarded as an option for mitigating the release of greenhouse gases from cement. While investigations on its use with cement in concrete works is widespread, there is a gap in literature about its impact as a soil stabiliser for flexible road pavements. This work studies the compaction behaviour of two lateritic soils stabilised with a blend of Portland cement (PC) and $C K C$ combined in CKC:PC ratios of $0: 1,1: 3,1: 1,3: 1$ and 1:0 with total binder percentages of 0 (control), 2.5, 5, 7.5 and 10 of the weight of soils. CKC was obtained by calcining clay samples sourced from south-west Nigeria at $700^{\circ} \mathrm{C}$ for 1 hour. Two lateritic soils samples were adopted and classified as A-1-a and A-2-6 based on AASHTO system. Corresponding fineness modulus were 2.18 and 4.33 with cation exchange capacities (CECs) of $1.678 \mathrm{meq} / 100$ gms and $1.738 \mathrm{meq} / 100$ gms respectively. The results show that, as the $\mathrm{CKC:PC}$ mixes varies, compaction behaviour of the stabilised A-2-6 soil was widely varied whereas it was minimally varied for the stabilised A-1-a soil. The differences in the particle sizes (fineness modulus) and CEC are adduced as factors responsible for these differences in compaction behaviour. However, the CECs of the soils is about the same. Thus, the differences in compaction performance could only be attributed to differences in the particles sizes of the soils. Statistical evaluation of differences in the results using ANOVA confirms that the differences for the A-2-6 soil are significant whereas that of the A-1-a soil are not.

Keywords: calcined kaolinite clay, ordinary Portland cement, stabilisation, compaction, cation exchange capacity, particle size
\end{abstract}

\section{Introduction}

The increasing emission of environmentally detrimental $\mathrm{CO}_{2}$, a Green House Gas (GHG) in the cement manufacturing and consumption processes has been considered as one of the contributors to environmental pollution and global warming [ 1 , $2,3]$. In this regards, attempts have been made to find suitable replacements for cement. The emergence of substances such as fly ash, silica fume, various biomass ash and geopolymers among others have been a response to this drive $[1,2,3,4]$. These supplementary cementitious materials (SCMs) or pozzolans are compounds of silicates or aluminosilicates, which reacts with calcium hydroxide $\left(\mathrm{Ca}(\mathrm{OH})_{2}\right)$ from the cement to form cementitious compound $[2,3,4]$. They could be adopted in replacing cement (partially and sometimes wholly) in civil engineering works.

Calcined kaolinite clay (CKC) is a pozzolan that has produced excellent results in cement concrete works $[1,2,5)$. It is produced by calcining or heat-treating kaolinite rocks/clay (hydrated aluminium silicate, $\mathrm{Al}_{2} \mathrm{Si}_{2} \mathrm{O}_{5}(\mathrm{OH})_{4}$ ) under controlled temperature ranging between $650^{\circ} \mathrm{C}$ and $900^{\circ} \mathrm{C}$, depending on the source $[1,2,6,7]$. The calcining alters the structure of the kaolinite rocks, removing the attached hydroxyl ions $\left(\mathrm{OH}^{-}\right)$in the process $[2,7]$.

Though CKC have been used to replace cement partially with commendable results in concrete works, there is a gap in the literature as to its consideration in soil stabilisation. Thus, the pattern of its effect on soils is not yet clear. This calls for investigations to ascertain if the reported upper edge in cement concrete works could be corresponded in soil stabilisation. This work investigated the compaction characteristics of lateritic soils stabilised with CKC-PC blends. The intention is to explore possible attributes of soils that can be used to explain the compaction behaviour of CKC-PC stabilised soils.

\section{Methodology}

Two sources of lateritic soils were identified and used for this work. Samples were obtained from two locations (both in South-west Nigeria) having soils that are characteristically different from one another. An area that had not been previously disturbed was identified at the two locations and excavated to depths not less than $1.0 \mathrm{~m}$ below the surface. Disturbed samples were collected into an airtight container, labelled and transported to the laboratory. The soils were labelled as samples A and B respectively.

The samples were subjected to soil classification tests at the soil laboratory based on the British Standard procedures [8], for classification using the American Association of State Highway and Transportation Officials (AASHTO) classification system. The system classifies soils using group indices, which are determined, as [9]:

$\mathrm{GI}=0.2 \mathrm{a}+0.005 \mathrm{ac}+0.01 \mathrm{bd}$ 
$\mathrm{a}=$ that portion of the percentage passing 200 sieve greater than $35 \%$ and not exceeding $75 \%(0-40)$

$\mathrm{b}=$ that portion of the percentage passing 200 sieve greater than $15 \%$ and not exceeding 55\% (0 - 40)

$\mathrm{c}=$ that portion of the liquid limit greater than 40 and not exceeding $60(0-20)$

$\mathrm{d}=$ that portion of the PI greater than 10 and not exceeding $30(0-20)$.

From the particle size analysis, the levels of fineness of the two soils were also determined and compared. The fineness modulus is determined by adding the cumulative percentages retained on each of sieves size $150 \mu \mathrm{m}, 300 \mu \mathrm{m}, 600 \mu \mathrm{m}, 1.18 \mathrm{~mm}, 2.36 \mathrm{~mm}$ and $4.75 \mathrm{~mm}$ respectively and dividing by 100 .

In addition, the soil samples were also subjected to chemical analysis test using X-ray Fluorescence (XRF). Their respective cation exchange capacities (CECs) were also determined in the laboratory.

CKC was obtained by calcining kaolinite clay samples sourced from its natural deposit in South-west Nigeria. The kaolinite was located at a level ranging from about 10 meters depth from the ground level, underlying a layer of lateritic soil. The samples were milled into powder and calcined at $700^{\circ} \mathrm{C}$ for 1 hour; the calcining specification based on earlier works on the same clay sample [10]. The calcining was done using an electric muffle furnace fitted with a temperature control device to adjust temperature to the target calcining temperature. The calcined clay samples were then sieved using a $90 \mu \mathrm{m}$ sieve and the portion passing through was used. This is based on the premise that particle sizes of cement ranged from the maximum of between 75-100 $\mu \mathrm{m}[11,12]$. The particle size of the pozzolan to be combined with it in stabilisation should therefore be within similar range. The CKC was also subjected to chemical analysis test using XRF for comparison with the standard for classification of materials as natural pozzolans [13]. The CEC was also determined as well.

The standard proctor compaction tests (British Light) were carried out in line with the procedures of [8] for compaction on soils for civil engineering purpose and of [14] for tests on stabilised soils. The portion of the lateritic soils passing the 20 $\mathrm{mm}$ test sieve was used. The stabilisers (CKC and PC) were applied in a definite format. They were combined in total percentages of 2.5, 5.0, 7.5 and 10 (of the weight of the soils) respectively with CKC:PC combining ratios of $0: 1,1: 3,1: 1$, $3: 1$ and 1:0 respectively. With the inclusion of the control $(0 \%$ total binder), 21 different compositions of soil-binders were adopted for each of the two soils.

For each CKC-PC-lateritic soil mix, four or five samples were compacted, each sample at increasing water content over the previous. The same was done for the control sample $(0 \%$ binder). The maximum dry densities (mdds) and optimum moisture contents (omcs) of the mixes were obtained from these tests. The tests were repeated two more times per CKCPC-lateritic soil mix and averages were determined.

The compaction results were then compared and explanations were found for possible differences, if any. In addition, comparison is drawn by running a statistical analysis to determine if any significant differences exist across the combining ratios as the total binder percentages increase. This analysis was executed using ANOVA tool on Microsoft Excel software package.

\section{Results}

\section{1. Properties of soils}

Lateritic soil sample A was dark-reddish brown silty sandy clay material. Sample B lateritic soil was light-reddish brown gravelly sandy clay; less reddish compared to sample A. There are specks with creamy/white colorations within the soil mass. The soil has fragments of stones identified by physical inspection. These soil samples are generally adopted for road works and especially suitable for stabilisation works.

The results of the particle size analysis of the two soils are detailed in Figs. $1 a$ and $1 b$. Sample A is a fine-grained (silty sandy clay) soil whereas sample B is gravelly (about $50 \%$ retained on $4.75 \mathrm{~mm}$ benchmark and almost no fines). These particle size results were consistent with the plasticity indices of the soils presented in Table 1. Typical of fine soils, sample A has higher plasticity with plasticity index of $20.5 \%$, whereas sample B has low value of $6.3 \%$. The table also presents the result of AASHTO group classification for the two soils. The soils were classified as A-2-6 (sample A) and A-1-a (sample B). These classifications indicate that the soils are amenable to stabilisation $[15,16]$. The fineness modulus obtained from the particle size result is also presented in Table 1. The fineness modulus for the A-2-6 soil was 2.18 whereas it was 4.33 for the A-1-a soil, indicating that the A-2-6 soil is twice as fine as the A-1-a soil.

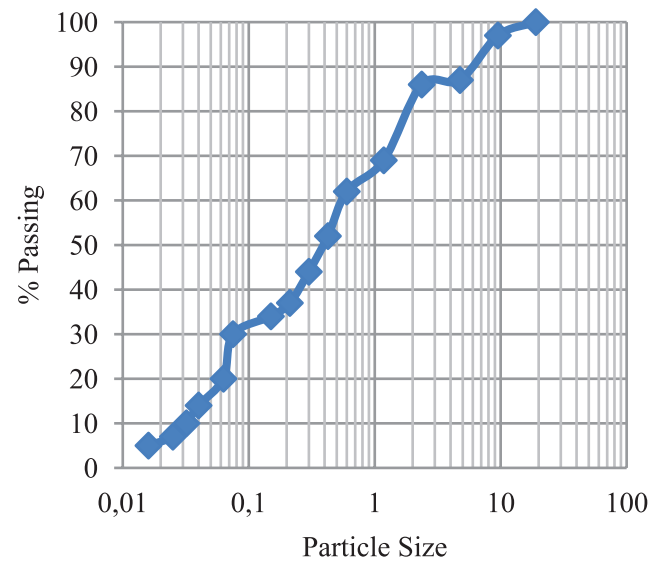

Fig. 1a. Particle size analysis for soil sample A

1a. ábra A jelü talaj minta szemcseméret eloszlása

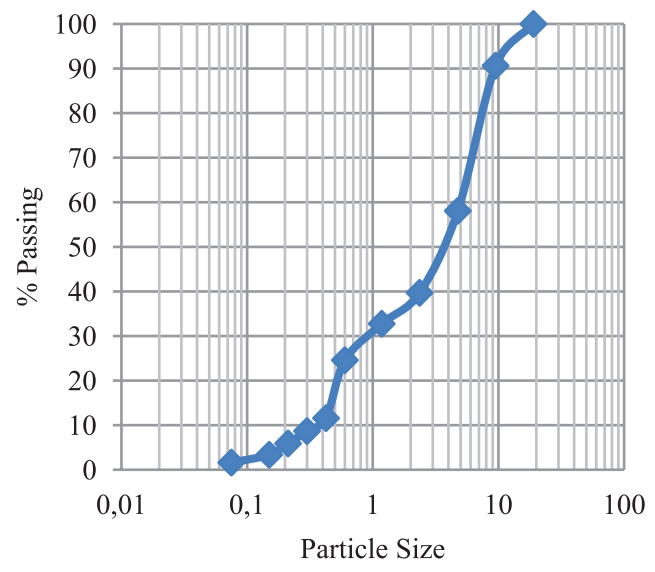

Fig. 1b. Particle size analysis for soil sample $B$

1b. ábra $B$ jelü talaj minta szemcseméret eloszlása 


\begin{tabular}{lccccccccc} 
Soil sample & $\begin{array}{c}\text { \% Passing } \\
\text { sieve No } \mathbf{1 0} \\
(\mathbf{2} \mathbf{~ m m})\end{array}$ & $\begin{array}{c}\text { \% Passing } \\
\text { sieve No } \mathbf{4 0} \\
(\mathbf{4 2 5} \boldsymbol{\mu m})\end{array}$ & $\begin{array}{c}\text { \% Passing } \\
\text { sieve No } \mathbf{2 0 0} \\
(\mathbf{7 5} \boldsymbol{\mu m})\end{array}$ & $\begin{array}{c}\text { Liquid } \\
\text { limit }\end{array}$ & $\begin{array}{c}\text { Plastic } \\
\text { limit }\end{array}$ & $\begin{array}{c}\text { Plasticity } \\
\text { index }\end{array}$ & $\begin{array}{c}\text { Group } \\
\text { index, } \\
\text { Gl* }\end{array}$ & $\begin{array}{c}\text { AASHTO } \\
\text { classification* }\end{array}$ & $\begin{array}{c}\text { Fineness } \\
\text { modulus }\end{array}$ \\
\hline A & $84 \%$ & $52 \%$ & $30 \%$ & $39.8 \%$ & $19.3 \%$ & $20.5 \%$ & 2 & A-2-6 & 2.18 \\
\hline B & $36 \%$ & $12 \%$ & $2 \%$ & $47.9 \%$ & $41.6 \%$ & $6.3 \%$ & 0 & A-1-a & 4.33 \\
\hline
\end{tabular}

*Classification and group indices are based on the AASHTO soil classification

Table 1. Physical properties of the lateritic soil samples

1. táblázat Laterit talaj minták fizikai jellemzöi

\begin{tabular}{|c|c|c|c|c|c|}
\hline Chemical constituents & CKC (\%) & & ASTM C618-12 requirement for pozzolans & Soil sample A & Soil sample B \\
\hline $\mathrm{SiO}_{2}$ & 41.08 & \multirow{3}{*}{95.22} & \multirow[t]{3}{*}{$\mathrm{SiO}_{2}+\mathrm{Al}_{2} \mathrm{O}_{3}+\mathrm{Fe}_{2} \mathrm{O}_{3} ; \geq 70 \%$} & 53.85 & 41.26 \\
\hline $\mathrm{Al}_{2} \mathrm{O}_{3}$ & 52.86 & & & 29.01 & 40.02 \\
\hline $\mathrm{FeO}_{3}$ & 1.28 & & & 6.03 & 4.32 \\
\hline $\mathrm{CaO}$ & 3.00 & & & 4.15 & 1.55 \\
\hline MgO & 0.10 & & & 0.04 & 0.00 \\
\hline $\mathrm{K}_{2} \mathrm{O}$ & 0.12 & & 1. $5 \% \max$ & 0.04 & 0.00 \\
\hline $\mathrm{Na}_{2} \mathrm{O}$ & 0.06 & & 1. $5 \% \max$ & 0.10 & 0.08 \\
\hline $\mathbf{P}_{2} \mathbf{O}_{5}$ & 0.03 & & & 0.07 & 1.06 \\
\hline $\mathrm{SO}_{3}$ & 0.12 & & $4 \% \max$ & 0.10 & 1.58 \\
\hline LOI & 1.16 & & $10 \% \max$ & 6.66 & 10.25 \\
\hline Total & 99.81 & & & 100.05 & 100.12 \\
\hline CEC (meq/100gm) & 2.455 & & & 1.738 & 1.678 \\
\hline
\end{tabular}

Table 2. Chemical analysis of the materials used

2. táblázat Vizsgált anyagok kémiai összetétele

The chemical analysis results are presented in Table 2. Typical of lateritic soils, the soils predominantly consists of silicates and aluminates. For the two soils, the oxides add up to about the same amount $-82.86 \%$ for the A-2-6 soil and $81.28 \%$ for the A-1-a soil respectively. However, the A-2-6 soil has more silicates. The A-2-6 soil has silicates constituents of $53.85 \%$ (more than half the total chemical constituents) and aluminate only about half of this (29.01\%). However, the silicate-aluminate ratio is almost equal for the A-1-a soil (41.26\%-40.02\%). Moreover, the CEC results as presented in Table 2 shows that the two soils have CEC of $1.678 \mathrm{meq} / 100 \mathrm{gm}$ (A-1-a soil) and $1.738 \mathrm{meq} / 100 \mathrm{gm}$ (A-2-6 soil).

\section{2. Properties of CKC}

The CKC came out as creamy-white material after calcining. The result of chemical analysis, also presented in Table 2, shows that the material passed the ASTM requirements with the constituents of $\mathrm{SiO}_{2}, \mathrm{Al}_{2} \mathrm{O}_{3}$ and $\mathrm{Fe}_{2} \mathrm{O}_{3}$ totalling 95.22\%; more than the required $70 \%$ minimum. Other conditions were satisfied as well signifying the suitability of the calcined clay as a pozzolan. The CEC of the pozzolan is also determined as $2.455 \mathrm{meq} / 100 \mathrm{gms}$.

\section{3. Compaction results}

The compaction results are presented in Figs. $2 a$ and $2 b$ for maximum dry densities and Figs. $3 a$ and $3 b$ for optimum moisture contents respectively. The unstabilised A-2-6 soil ( $0 \%$ binder) has the mean maximum dry density (mdd) of 1.77 $\mathrm{kg} / \mathrm{m}^{3}$ (Fig. 2a) while the corresponding optimum moisture content (omc) is $15.4 \%$ (Fig. 3a). For A-1-a soil, corresponding values are $1.87 \mathrm{~kg} / \mathrm{m}^{3}$ (Fig. 2b) and 9.1\% (Fig. 3b). The mdd is higher for the A-1-a soil possibly due to the presence of coarser particles, which are likely to be of higher mass than the particles of the A-2-6 soil. As such, the densification brought about by compaction will lead to higher mdd for the A-1-a soil. However, the corresponding omc is lower. This agrees with [17] that this is typical of soils with low plasticity index. Moreover, Figs. $2 a$ and $2 b$ show a general downward trend in the mdd as total binder increases for the two stabilised soils. For each of the five binder mix ratios, the mdd initially increased from control (0\%); rising to the peak at $2.5 \%$ total binder content in all the cases of the binder mix ratios considered. Thereafter, the mdd reduced gradually as the total binder percentages increased from $2.5 \%$ up to $10 \%$ total binder content. Expectedly, the omc graph took a reverse trend for the two soils.

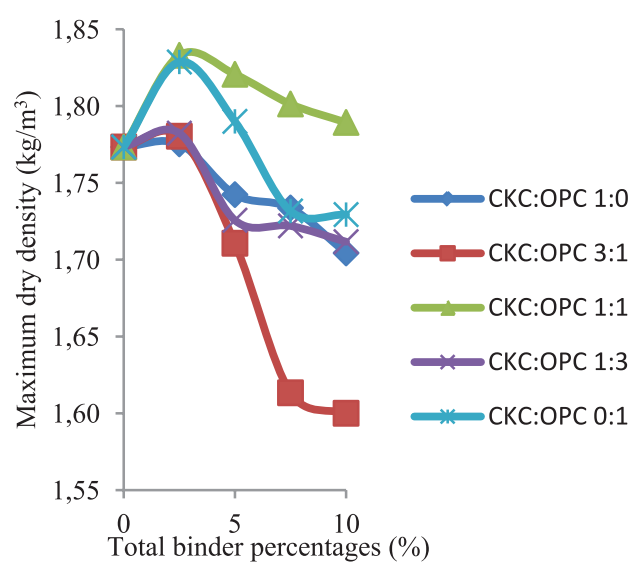

Fig. 2a. Graph of mdd - stabilised A-2-6 soil (sample A) 2a. ábra Stabilizált A-2-6 talaj (A jelü minta): mdd eredmények 


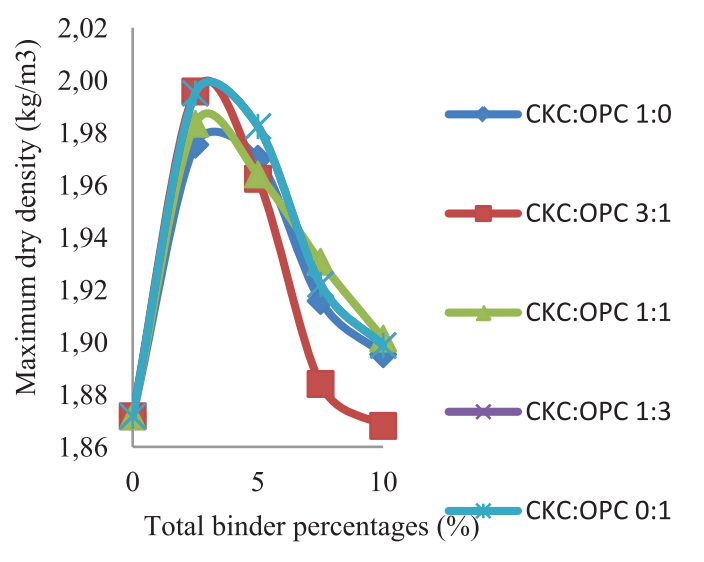

Fig. 2b. Graph of mdd-stabilised A-1-a soil (sample B)

2b. ábra Stabilizált A-1-a talaj (B jelü minta): mdd eredmények

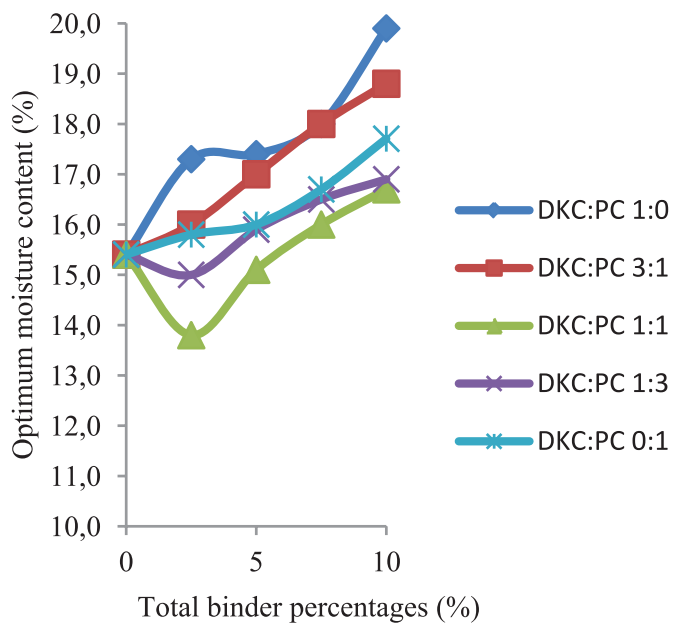

Fig. 3a. Graph of omc-stabilised A-2-6 soil (sample A)

3a. ábra Stabilizált A-2-6 talaj (A jelü minta): omc eredmények

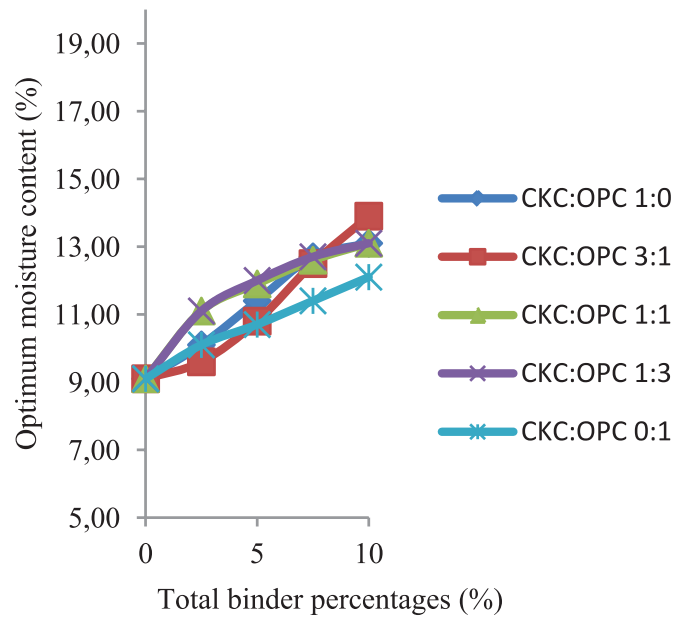

Fig. 3b. Graph of omc-stabilised A-1-a soil (sample B)

3b. ábra Stabilizált A-1-a talaj (B jelü minta): omc eredmények

The general trend in the mdd is attributed to the formation of cementitous products from the added binders, which aids the cementation and agglomeration of the particles of the stabilised soils. This results to formation of coarse particles, which occupy larger spaces, implying an increased volume. Once volume increases, the density reduces for the same weight of soil. It is premised that the degree of flocculation/ agglomeration increases with increasing content of binders (increasing percentages), leading to further formation of large particles and increasing volumes for the same soil weight. As such, the mdds will further reduce as more binders are added. In another vein, the observed trends can also be explained using the concept of the replacement of lateritic soils by less dense binder materials such as CKC and PC. The replacement causes a reduction in the overall weight, and by extension, the dry density. The more the replacement, the more the density reduces $[15,18]$. However, the initial increase in mdd at $2.5 \%$ could be due to the filler effect of the binder which increases the density.

The increasing trend in moisture content is also typical. With the increasing addition of cementitious binders, more moisture is needed to facilitate movement of ions in the hydration/ pozzolanic processes $[4,18,19]$. As a result, more water is added, increasing the moisture content. Thus, typical of the effect of stabilisers on the compaction characteristics of soils, the mdd generally decreased at increasing total binder content while the omc generally took a reverse trend. These identified trends are typical of compaction behaviour of lateritic soil stabilisation with binders such as cement, lime, rice husk ash, bamboo leaf ash etc $[18,19,20,21]$.

Though the trend as binder percentage increase was similar for the two soils, the results show that, across the binder mix ratios, the mdds are not the same in values for A-2-6 soil (Fig. $2 a$ ). The mdds at the $2.5 \%$ total binder level for CKC:PC ratio $1: 1$ and $0: 1$ were $1.833 \mathrm{~kg} / \mathrm{m}^{3}$ and $1.829 \mathrm{~kg} / \mathrm{m}^{3}$ respectively. The mix ratios of $3: 1,1: 3$ and 1:0 had mdd values of $1.780 \mathrm{~kg} / \mathrm{m}^{3}$, $1.782 \mathrm{~kg} / \mathrm{m}^{3}$ and $1.775 \mathrm{~kg} / \mathrm{m}^{3}$ respectively. Also, corresponding values at $5.0 \%$ were $1.821 \mathrm{~kg} / \mathrm{m}^{3}$ and $1.790 \mathrm{~kg} / \mathrm{m}^{3}$ for CKC:PC ratio $1: 1$ and $0: 1$ while mix ratios of 3:1, 1:3 and 1:0 had mdds of $1.711 \mathrm{~kg} / \mathrm{m}^{3}, 1.726 \mathrm{~kg} / \mathrm{m}^{3}$ and $1.742 \mathrm{~kg} / \mathrm{m}^{3}$ respectively. These differences were also reported at the other binder levels (7.5\% and $10.0 \%)$. However, for A-1-a soil, the graphs show that performances are close across the mix ratios that it becomes difficult to distinguish between them (Fig. 2b). In other words, at each binder percentage, the differences in mdds across the five binder mix ratios were not very clear-cut. At $2.5 \%$, the soil stabilised using CKC:PC mix ratios of 3:1 and 0:1 had about the same mdds; $1.996 \mathrm{~kg} / \mathrm{m}^{3}$ and $1.995 \mathrm{~kg} / \mathrm{m}^{3}$ respectively. The mdds for mix ratios 1:0 and 1:3 also had almost the same value of $1.975 \mathrm{~kg} / \mathrm{m}^{3}$ and $1.974 \mathrm{~kg} / \mathrm{m}^{3}$ respectively. The soil stabilised with binder mix ratio $1: 1$ had mdd of $1.983 \mathrm{~kg} / \mathrm{m}^{3}$. The mdds at $5 \%$, and $7.5 \%$ also showed similar tendencies. It was only at $10 \%$ total that there seem to be marked differences in the mdds across the binder mixes. In a similar manner, the variations of the corresponding omcs across the binder mixes show the same trend as the mdds. This is as shown in Figs. $3 a$ and $3 b$ for the two stabilised soil samples.

The variations of the compaction characteristics of the stabilised soils across the different binder mixes can be attributed to the differences in particle size and CEC of the soils. Soils with fine particles possesses high specific surface but the total volume of voids or pore spaces is low. The cementitous products could easily fill up the pore spaces and cause agglomeration of the particles. Thus, the variations in the volume of cementitous products formed 
due to the variations in binder mixes could easily be reflected in the compaction attributes of the A-2-6 soil being a fineparticle soil. However, the A-1-a soil with larger particles possesses larger pore spaces. This requires more volumes of cementitous products to fill. Thus, the effect of varying the binder mixes only will be felt at high binder contents. This explains why differences in compaction behaviour across the binder mixes became only visible at about $10 \%$ binder content. The CEC can also influence pozzolanic reactions as well. However, the CECs of the two soils are almost the same (1.738 meq/100gm and $1.678 \mathrm{meq} / 100 \mathrm{gm}$ respectively). Thus, the differences noticed in the compaction behaviour of the two stabilised soils cannot be significantly attributed to their CECs. Moreover, the pozzolan CKC with a higher CEC of $2.455 \mathrm{meq} / 100 \mathrm{gm}$ is likely to prefentially participate in cation exchange reaction (pozzolanic reaction) between the excess lime from cement hydration and available aluminosilicate material. Thus, rather than the soils, the pozzolan with a higher CEC goes into the pozzolanic reaction as the preferred source of aluminosilicates.

\section{4. Statistical analysis}

The observed differences in the mdds and in the omcs across the five binder mixes at each level of binder content (the percentages) were tested for significance using ANOVA statistical tool. The result shows that, for mdd, ANOVA's $\mathrm{F}$ (4.17) is greater than the critical $\mathrm{F}$ value of 3.06 for the A-2-6 soil (Table 3). The corresponding ANOVA analysis on omc gives the ANOVA's $F$ being 4.03 versus the critical value of 3.06 ( $p \leq 0.05$ in both cases). These results show that the variations in the binder mix ratios have given rise to signifcant differences in the compaction charateristics of the stabilised soils.

\begin{tabular}{lcccc} 
& $\begin{array}{c}\text { mdd for } \\
\text { sample A }\end{array}$ & $\begin{array}{c}\text { mdd for } \\
\text { sample B }\end{array}$ & $\begin{array}{c}\text { omc for } \\
\text { sample A }\end{array}$ & $\begin{array}{c}\text { omc for } \\
\text { sample B }\end{array}$ \\
\hline F & 4.18 & 0.19 & 4.03 & 0.56 \\
Fcritical & 3.06 & 3.06 & 3.06 & 3.06 \\
P-value & 0.02 & 0.94 & 0.02 & 0.70 \\
\multicolumn{2}{r}{ Table 3. Summary of ANOVA (single factor) } & & \\
3. táblázat & Egy faktoros ANOVA eredményei
\end{tabular}

Moreover, for the A-1-a soil, Table 3 shows that there are no statistically significant differences in the mdd values across the binder mix ratios at each total binder level. The $F$ value of 0.19 was less than the critical F's value of 3.06 $(\mathrm{p}=0.94)$. For omc, the critical value of $\mathrm{F}(3.06)$ was more than the F's value of $0.56(\mathrm{p}=0.70)$. Thus, it implies that, irrespective of any binder combination, about the same results are observed.

\section{Conclusions}

From the results, it can be concluded that compaction characteristics of CKC-stabilised soil depends on the attributes of the soil; the particle size in particular. Considering this, it can be concluded that CKC as a pozzolan could not solely alter behavior through pozzolanic stabilisation. Rather, the soils' properties also have a significant role to play in the compaction outcome. Thus, in the use of CKC-cement blends for stabilisation for flexible road pavement, the property of the soil is a major factor to consider. The pozzolanic potential of CKC does not override this factor.

\section{References}

[1] Aboubakar, M. A. - Ganjian, E. - Pouya, H. - Akashi, A. (2013): A study on the effect the addition of thermally treated Libyan natural pozzolan has on the mechanical properties of ordinary Portland cement mortar, International Journal of Science and Technology, Vol. 3, No. 1, pp. 79-84.

[2] Justice, J. M. (2005): Evaluation of metakaolins for use as supplementary cementitious materials. An Unpublished MSc thesis, School of Material Science and Engineering, Georgia Institute of Technology.

[3] Kolovos, K. G. - Asteris, P. G. - Cotsovos, D. M. - Badogiannis, E. Tsivilis, S. (2013): Mechanical properties of soilcrete mixtures modified with metakaolin. Construction and Building Materials, Vol. 47, pp. 10261036. https://doi.org/10.1016/j.conbuildmat.2013.06.008

[4] Amu, O. O. - Adetuberu, A. A. (2010): Characteristics of bamboo leaf ash stabilisation on lateritic soil in highway construction. International Journal of Engineering and Technology, Vol. 2, No. 4, pp. 212-219.

[5] Olonade, K. A - Jaji, M. B - Adekitan, O. A. (2016): Experimental Comparison of Selected Pozzolanic Materials. Proceedings of the $2^{\text {nd }}$ International Conference on Advances in Cement and Concrete Technology in Africa, Dares Salaam, Tanzania, January 27 -29, pp. 309-314.

[6] Ilić, B. R. - Mitrović, A. A. - Miličić, L. R. (2010): Thermal treatment of kaolin clay to obtain metakaolin, Hemijska industrija, Vol. 64, No. 4, pp. 351-356. https://doi.org/10.2298/HEMIND100322014I

[7] Justice, J. M. - Kennison, L. H. - Mohr, B. J. - Beckwith, S. L. - McCormick, L. E. - Wiggins, B. - Zhang, Z. Z. - Kurtis, K. E. (2005): Comparison of two metakaolins and silica fume used as supplementary cementitious material. Proceeding of the Seventh International Symposium on Utilization of High-Strength/High Performance Concrete, Washington DC, 20-24 June, 2005.

[8] BS 1377 (2000) British standard methods for testing soils in civil engineering, parts 1 - 9. British Standards Institute, London.

[9] Das, B. - Sobhan, K. (2013): Principles of Geotechnical Engineering, $8^{\text {th }}$ ed. Cengage Learning, US.

[10] Adekitan, O. - Ayininuola, G. M. - Jaji M. B. (2016): Optimizing the Thermal Treatment of Abeokuta Kaolin (South-West Nigeria) for Production of Natural Pozzolan. Proceedings of the $2^{\text {nd }}$ International Conference on Advances in Cement and Concrete Technology in Africa, Dar es Salaam, Tanzania, 27-29, January 2016. BAM Federal Institute for Materials Research and Testing, Berlin, pp. 99-105.

[11] Fernandez, R. - Martirena, F. - Scrivener, K. L. (2011): The origin of the pozzolanic activity of clay minerals: A comparison between kaolinite, illite and montmorillonite, Cement and Concrete Research, Vol. 41, pp. 113-122. https://doi.org/10.1016/j.cemconres.2010.09.013

[12] Ferraris, C. F. - Hackley, V. A. - Avil'es, A. I. (2004): Measurement of particle size distribution in Portland cement powder: analysis of ASTM round robin studies. Cement, Concrete, and Aggregates, Vol. 26, No. 2, pp. 1 - 11. https://doi.org/10.1520/CCA11920

[13] ASTM C618-12. (1994): Standard specification for coal fly ash and raw or calcined natural pozzolan for use in concrete. ASTM International, US.

[14] BS 1924 (2000): British standard methods of testing for stabilised soils. British Standards Institute, London.

[15] Jimoh, Y. A. - Apampa, O. A. - Adekitan, O. (2014): Enhancing the agricultural value chain through the use of corn cob ash in pavement construction. Technical Transactions of the Nigerian Society of Engineers, Vol. 48, No. 1, pp. 13 - 22.

[16] Indiana Department of Transportation (INDOT), (2008). Design procedures for soil modification or stabilisation. Report of Production 
Division, Office of Geotechnical Engineering, Indiana Department of Transportation, US.

[17] Laskar, A. - Pal, S. K. (2012): Geotechnical characteristics of two different soils and their mixture and relationships between parameters. EJGE 17, pp. $2821-2832$.

[18] Grytan, S. - Rafiqul, I. - Muhammed, A. - Rokonuzzaman (2012): Study on the geotechnical properties of cement based composite fine-grained soil. International Journal of Advanced Structures and Geotechnical Engineering, Vol. 1, No. 2, pp. $42-49$.

[19] Otoko, G. R. (2014): On the economic use of cement in soil stabilisation. International Journal of Engineering and Technology Research, Vol. 2, No. 1, pp. 1-7.

[20] Ola, S.A. (1983): Tropical soils in engineering practice. Balkema Publishers, Rotterdam, Netherlands.

[21] Amu, O. O. - Bamisaye, O. F. - ad Komolafe, I. A. (2011): The suitability and lime stabilisation requirement of some lateritic soil samples as pavement material. International Journal of Pure and Applied Sciences and Technology, Vol. 2, No. 1, pp. 29-46.

$\underline{\text { Ref.: }}$

Ayininuola G. M. - Adekitan, O. A.: Compaction characteristics of lateritic soils stabilised with cement-calcined clay blends

Építőanyag - Journal of Silicate Based and Composite Materials, Vol. 69, No. 2 (2017), 33-39. p.

https://doi.org/10.14382/epitoanyag-jsbcm.2017.7
Cementtel és kalcinált agyaggal stabilizált laterit talajok tömöríthetőségi jellemzői

A kalcinált kaolin egyike azoknak a cement kiegészító anyagoknak, amelyekkel csökkenthetố a cement felhasználásából eredô üvegházhatású gázok kibocsátásának mértéke. A betonban történố felhasználás szakirodalma gazdag, azonban a rugalmas útpálya szerkezetek alatti talaj stabilizáció terén kevés vizsgálat történt. Jelen cikk ezt mutatja be. Két laterit talaj stabilizálását tanulmányozták a kutatás során. A vizsgált portlandcement (PC) : kalcinált kaolin (CKC) arányok a következôk voltak; CKC:PC = 0:1, 1:3, 1:1, 3:1 és 1:0. A talajok tömegére vonatkoztatott kötő́anyag arán 0 (kontroll), és 2.5, 5, 7.5, 10\% volt. A kalcinált kaolint laboratóriumban állították elō, dél-nyugat Nigériából származó kaolin $700^{\circ} \mathrm{C}$-on történô, 1 órás hôkezelésével. A vizsgált laterit talajok AASHTO szerinti osztályozása A-1-a és A-2-6 volt, 2,18 és 4,33 finomsági modulussal, illetve 1,678 meq/100 gms és 1,738 meq/100gms kation cserekapacitással. A vizsgálati eredmények szerint aa A-2-6 osztályú laterit talaj minta tömöríthetôsége nagymértékben változott a kötôanyag CKC:PC arányának változtatásával, míg az A-1-a osztályú talajnál ez a hatás minimális volt. Ennek oka elsôsorban a szemeloszlásban kereshetô, mert a két vizsgált talaj kation cserekapacitása csaknem teljesen azonos.

Kulcsszavak: kalcinált kaolinit agyag, normál Portland cement, stabilizálás, tömörítés, kation cserekapacitás, szemcseméret
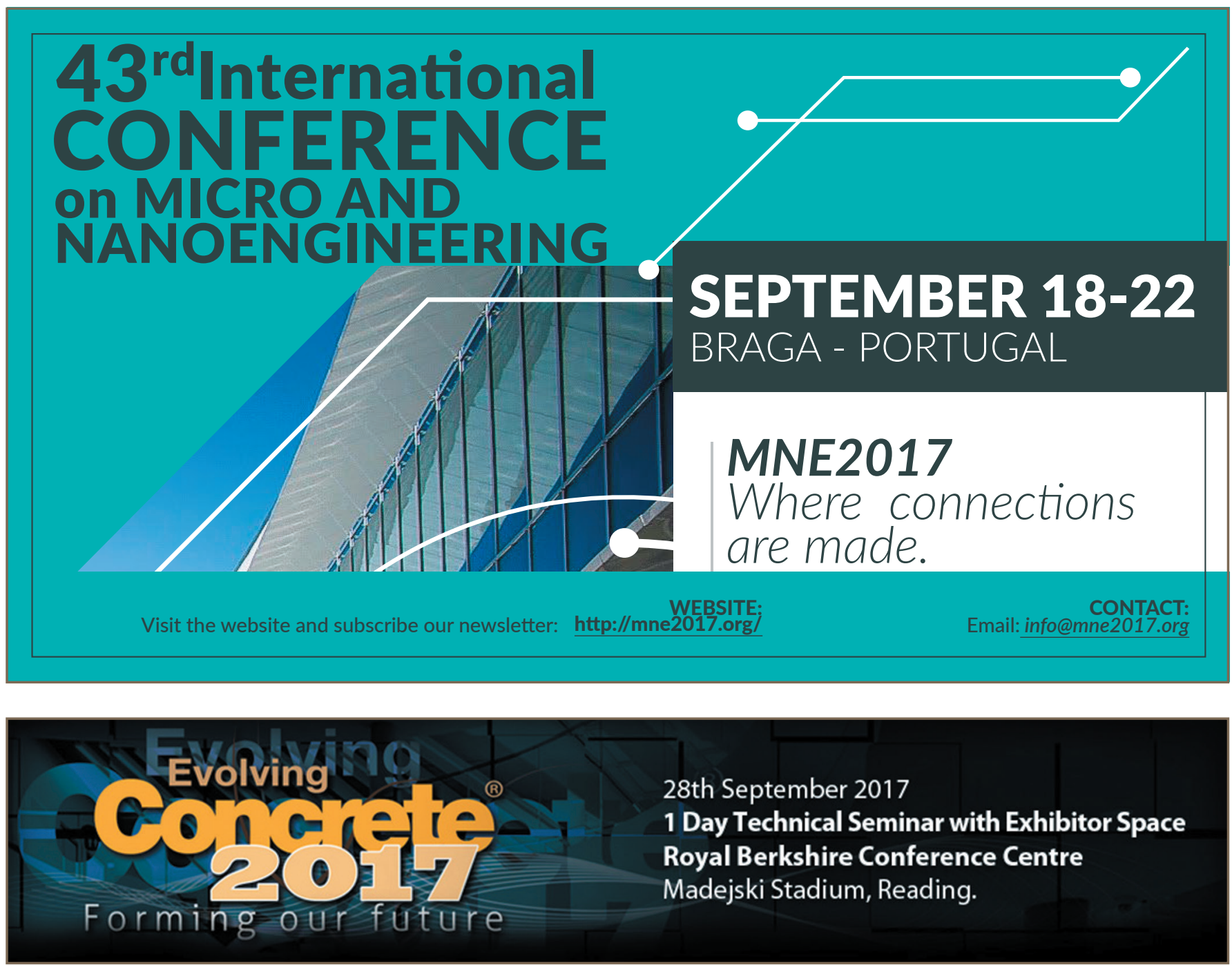